ROCZNIKI FILOZOFICZNE

Tom LXVIII, numer $4-2020$

DOI: https://doi.org/10.18290/rf20684-6

TADEUSZ PABJAN

\title{
PROJEKT CZY EWOLUCJA? \\ STWÓRCZE DZIAŁANIE BOGA W ŚWIECIE PRZYRODY
}

\section{WSTĘP}

Wiadomo nie od dziś, że pogranicze teologii, filozofii i nauk empirycznych to obszar obfitujący w ważne zagadnienia, które nie mają prostej i jednoznacznej interpretacji. Problem ujęty w tytule tego artykułu z całą pewnością należy do właśnie takich zagadnień. O tym, że z teologicznego punktu widzenia problematyka stworzenia jest zagadnieniem o fundamentalnym charakterze, i że jego interpretacja ma kluczowe znaczenie dla wszystkich innych kwestii dyskutowanych $\mathrm{w}$ teologii, nie trzeba nikogo przekonywać. Ranga tego zagadnienia jest oczywista i nie podlega żadnej dyskusji to, że prawda o stworzeniu świata przez Boga jest swego rodzaju teologicznym aksjomatem, którego zakwestionowanie byłoby równoznaczne z wyjęciem kamienia węgielnego leżącego u podstaw gmachu całej teologii. Dyskusji nie podlega zatem to, że Bóg jest stwórcą. Podlega jej za to co innego, a mianowicie, jak należy rozumieć sam akt stworzenia. Spór o interpretację tego zagadnienia ma długą historię, której ślady utrwalone zostały w teologicznych i filozoficznych traktatach powstałych już w starożytności, średniowieczu i pierwszych epokach czasów nowożytnych. Wiele jednak wskazuje na to, że najciekawsze (a może również najważniejsze) epizody tej historii — historii sporu o rozumienie stwórczego działania Boga — mają związek z powstaniem nauk empirycznych, które opisują i wyjaśniają funkcjonowanie świata przyrody.

$\mathrm{W}$ interpretacjach teologicznych — które od pierwszych wieków chrześcijaństwa pozostawały pod wpływem filozofii dualistycznej — Bóg jawi się

Ks. dr hab. TADEUSZ PABJAN — prof. UPJPII, pracownik naukowo-dydaktyczny Uniwersytetu Papieskiego Jana Pawła II w Krakowie, kierownik Katedry Filozofii na Wydziale Teologicznym sekcja w Tarnowie UPJPII; e-mail: tpabjan@wp.pl; ORCID: https://orcid.org/0000-0003-1483026X. 
jako stwórca całej istniejącej realnie rzeczywistości: zarówno świata materii, jak i świata ducha. O ile w przypadku świata duchowego dane nauk przyrodniczych nie są teologom szczególnie potrzebne do zinterpretowania tego, w jaki sposób dokonuje się stwórcze działanie Boga, o tyle w przypadku materialnego świata przyrody pojawia się zasadnicza trudność dotycząca takiej interpretacji. Czy bowiem można uznać, że nauki przyrodnicze, opisujące działanie materii podległej prawom przyrody, opisują zarazem stwórcze działanie Boga, który — zgodnie z koncepcją ciągłego stwarzania (creatio continua) - nieustannie daje istnienie światu przyrody? A jeśli tak, to w jakim sensie funkcjonowanie przyrody można uznać za przejaw stwórczego działania Boga? Czy Bóg działa w przyrodzie bezpośrednio jako przyczyna o charakterze fizykalnym i czy w związku z tym nauki przyrodnicze mogą wykrywać Jego działanie i dostarczać empirycznych dowodów na Jego stwórczą obecność w świecie materii? Czy też Stwórca działa w przyrodzie pośrednio - jako przyczyna o charakterze ontycznym, która jest obecna we wszystkich przyczynach fizykalnych i działa za ich pośrednictwem - i dlatego nauki przyrodnicze nie mogą odkrywać bezpośrednich dowodów Jego stwórczego działania?

Choć problem zamknięty w tych pytaniach był przedmiotem filozoficzno-teologicznych analiz na długo przed powstaniem nauk przyrodniczych, to jednak dopiero rozwój tych nauk postawił to zagadnienie w dostatecznie jaskrawym świetle, które pozwoliło zauważyć niewidoczne wcześniej aspekty tej trudności. $Z$ oczywistych względów szczególną rolę odegrał w tym procesie rozwój nauk biologicznych, które począwszy od połowy XIX w. rozwijają się w paradygmacie określonym przez teorię ewolucji ${ }^{1}$. Nie ma wielkiej przesady w stwierdzeniu, że wszystkie współczesne epizody sporu o stwórcze działanie Boga w świecie przyrody są zdominowane tematyką nawiązującą w taki czy inny sposób właśnie do tej teorii. W szczególności, współczesna dyskusja dotycząca tego zagadnienia ukierunkowana jest na ustalenie tego, czy teoria ewolucji nadaje się do tego (a jeśli tak, to w jakim zakresie) by nadać jej teologiczną interpretację wyrażającą stwórcze działanie Boga w świecie przyrody. Chodzi w tym przypadku również o znalezienie odpowiedzi na pytanie, jaką konkretnie rolę odgrywa Stwórca w procesach ewolucyjnych. Celem niniejszego artykułu jest krótkie przedstawienie oraz poddanie krytycznej analizie kilku wybranych argumentów, które pojawiają się w tej dyskusji.

\footnotetext{
${ }^{1}$ Pod określeniem „teoria ewolucji” będę w tym artykule rozumiał współczesną (tzw. syntetyczną) teorię ewolucji.
} 


\section{KREACJONIZM \\ „WŁAŚCIWIE” I „NIEWŁAŚCIWIE” ROZUMIANY}

Spór o interpretację stwórczego działania Boga w świecie przyrody jest dobrym przykładem interdyscyplinarnej dyskusji, która ujawnia przynajmniej kilka istotnych słabości każdej ze stron biorących udział w tego typu przedsięwzięciu. Gdy idzie o teologów, to ich podstawową „słabością” jest nagminne lekceważenie nauk przyrodniczych, a konkretnie tego, co te nauki mają do powiedzenia na temat świata materii. Adepci teologii bardzo często nie tylko nie dostrzegają żadnego problemu w tym, że ich interpretacje są całkowicie oderwane od obowiązującego obrazu świata (który jest obrazem naukowym - w tym sensie, że tworzące ten obraz informacje pochodzą z obowiązujących teorii nauk przyrodniczych), ale nawet sądzą, że lekceważenie nauk przyrodniczych jest dla teologii podejściem wskazanym i w jakiś sposób „uszlachetniającym” i „oczyszczającym” metodę tej dyscypliny. Nic dziwnego, że przy takim podejściu trudno mówić o jakimkolwiek dialogu pomiędzy nauką i wiarą — dialog jest w tym przypadku wykluczony z tej prostej przyczyny, że teolog, który poznał prawdy objawione, nie widzi żadnej potrzeby rozmowy z przyrodnikiem, bo sądzi, że żadna inna prawda (poza objawioną) nie jest mu do niczego potrzebna ${ }^{2}$.

O tym, jak krótkowzroczne jest to podejście, i do jak groźnych prowadzi konsekwencji, pisano już wielokrotnie ${ }^{3}$, a analiza argumentów za tym, że teolog musi odwoływać się do aktualnego obrazu świata, wprowadzałaby zbyt obszerny wątek, odbiegający od tematyki tego opracowania, i dlatego zostanie tu pominięta. Warto jednak w tym miejscu podkreślić to, że pokusa lekceważenia nauk przyrodniczych jest $\mathrm{w}$ teologii nieustannie obecna, i że ujawnia się ona również w wielu argumentach wykorzystywanych w sporze o stwórcze działanie Boga w świecie przyrody, i w szczególności, o teologiczną interpretację teorii ewolucji. Teolog, który nie czuje się kompetentny do tego, by wypowiadać się na temat teorii ewolucji (zupełnie inną sprawą

\footnotetext{
2 Jeden ze znanych mi teologów w następujący sposób uzasadniał to, że on sam nie musi brać pod uwagę naukowego obrazu świata, i nie musi troszczyć się o dialog z nauką: „Teologia daje nam dostęp do źródła prawdy i dlatego nie musimy tej prawdy nigdzie indziej szukać. To raczej naukowcy niech sami przyjdą do tego źródła i z niego zaczerpną".

${ }^{3}$ Por. np. Andrzej Bronk, Zrozumieć świat współczesny (Lublin: Towarzystwo Naukowe KUL, 1998), 203-256; Michał Heller, Sens życia i sens wszechświata. Studia z teologii wspótczesnej (Tarnów: Biblos, 2002); Heller, Czy fizyka jest nauka humanistyczną? (Tarnów: Biblos, 1998), 143-156; Tadeusz PaBJAn, Anatomia konfliktu. Między nowym ateizmem a teologia nauki (Kraków: Copernicus Center Press, 2016), 62-67.
} 
jest to, czy ten brak kompetencji wynika z niemożliwego do przekroczenia stopnia trudności danego zagadnienia, czy też jest konsekwencją tego, że sięgnięcie po podręcznik z biologii wymagałoby od teologa dodatkowego wysiłku), bardzo często woli bowiem zasłonić się właśnie tym argumentem, że dane nauk przyrodniczych nie są potrzebne do tego, by poprawnie zinterpretować problem stwórczego działania Boga w świecie przyrody.

Kolejną słabością teologii, która nie pozostaje bez związku z lekceważeniem nauk przyrodniczych, jest zbyt łatwe uleganie innej pokusie, która również jest nieustannie obecna $\mathrm{w}$ naukowej działalności teologa. Tą pokusą jest brak intelektualnej pokory, wynikający albo ze wspomnianego wcześniej przekonania o „wyższości” i „zupełności” prawdy objawionej, która jest swego rodzaju punktem odniesienia dla całej teologii, albo mający związek z pewnym specyficznym stylem uprawiania teologii. Styl ten charakteryzuje się mocną wiarą w to, że treść wszystkich kluczowych dla teologii pojęć można w sposób jednoznaczny ustalić i zamknąć w określonych terminach (zaczerpniętych np. $\mathrm{z}$ jakiegoś systemu filozoficznego), które w sposób adekwatny i wyczerpujący oddają znaczenie tych pojęć. Takiej postawie towarzyszy często brak jakichkolwiek wątpliwości co do tego, że zbudowany $\mathrm{w}$ taki sposób system pojęć jest $\mathrm{w}$ rzeczywistości najlepszym $\mathrm{z}$ możliwych (a może nawet jedynym możliwym!) sposobem ujęcia prawdy objawionej. Chociaż wiadomo skądinąd, że teologii nie da się na dłuższą metę uprawiać właśnie w taki sposób - bo język teologiczny zawsze będzie zbyt ubogi wobec rzeczywistości, którą przy pomocy tego języka próbuje się opisać ${ }^{4}$, a określony sposób tego opisu (np. wybór takiego, a nie innego systemu pojęć) nie daje żadnych podstaw do tego, by inne, alternatywne sposoby uznać za „gorsze” lub „mniej wartościowe” — to jednak wielu teologów wydaje się o tym zapominać. Można się o tym przekonać, czytając niektóre publikacje dotyczące choćby właśnie stwórczego działania Boga w świecie przyrody, rozpatrywanego w kontekście teorii ewolucji.

Dobrym przykładem ilustrującym takie podejście jest następująca wypowiedź jednego z teologów, który uzasadnia, że prawdy o stworzeniu świata przez Boga nie da się w żaden sposób pogodzić z teorią ewolucji, bo „właściwe" rozumienie tej prawdy daje tylko tomizm, który nie przewiduje możliwości ewolucyjnego rozwoju stwarzanych przez Boga organizmów: „Właściwie rozumiany kreacjonizm i ewolucjonizm są poglądami nie do pogodzenia. To jakby przyjmować istnienie kwadratury koła. Gdy mówimy o kreacjonizmie ex nihilo, to za św. Tomaszem twierdzimy, że wyprowa-

\footnotetext{
${ }^{4}$ Por. Heller, Sens życia, 65-85; PaBJan, Anatomia konfliktu, 134-138.
} 
dzany jest w ten sposób do istnienia byt, a nie jakaś masa, niezorganizowana magma, z której dopiero coś może wyniknąć. Byty są wyprowadzane do istnienia jako całości, a więc razem ze swoją istotą i istnieniem, substancją i przypadłościami, z formą i istnieniem. Byt jest określony od początku swojego istnienia. Ma nadaną formę, a więc jest czymś i ma nadaną naturę, czyli do czegoś zmierza, do czegoś się rozwija. Tymczasem w szeroko rozumianym ewolucjonizmie wszystko dzieje się z przypadku. Przypadek rządzi

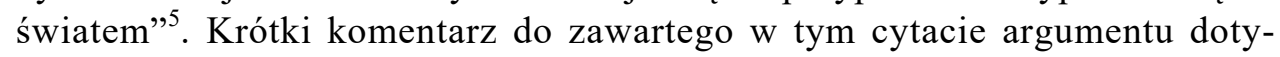
czącego przypadku, który rzekomo nie daje się uzgodnić z teologiczną prawdą o stworzeniu, znajdzie się w dalszej części tego artykułu (w tym miejscu wypada tylko wspomnieć, że sam św. Tomasz nie miał wątpliwości co do tego, iż „Boża opatrzność nie wyklucza zdarzeń przypadkowych i losowych"6, i dlatego zastanawia to, dlaczego autor powołujący się na Akwinatę nie uważał za stosowne odnieść się do tej — jakby nie patrzeć, bardzo istotnej - okoliczności). W tym kontekście natomiast warto zauważyć, że przywołany cytat dobrze ilustruje wspomniany wcześniej styl uprawiania teologii. Czytając taki tekst trudno nie odnieść wrażenia, że jego autor rzeczywiście jest święcie przekonany co do tego, iż z powodzeniem udało się mu całą prawdę objawioną zamknąć w pojęciach określonego systemu filozoficznego (w tym konkretnym przypadku jest nim tomizm), i że w związku $\mathrm{z}$ tym nie tylko nie musi on brać pod uwagę żadnego innego systemu pojęć - który tę samą prawdę mógłby wyrazić w nieco inny sposób - ale jest również uprawniony do tego, by własną interpretację określić mianem „właściwego" rozumienia kreacjonizmu. Oznacza to oczywiście, że wszystkie inne interpretacje należy uznać za „niewłaściwe” rozumienie tej koncepcji.

Dla analizowanego w tym artykule tematu nie jest istotne to, że taki sposób uprawiania teologii $\mathrm{w}$ praktyce bardzo często zaczyna bardziej przypominać żonglowanie pojęciami określonego systemu filozoficznego niż faktyczne poszukiwanie rozwiązania danego problemu; i nic dziwnego, że gdy pojawia się potrzeba zinterpretowania poglądu opartego na pojęciu spoza tego systemu, to nagle okazuje się, iż jest to pogląd „nie do pogodzenia” z całym systemem. Istotny jest $\mathrm{w}$ tym przypadku sam mechanizm odpowiedzialny za to, że każdy autor - przykład dotyczy teologa, ale z oczywistych względów te sama prawidłowość dotyczy również filozofa i naukowca-przyrodnika - własną interpretację danej koncepcji jest skłonny traktować jako jej „właściwe” i „para-

\footnotetext{
${ }^{5}$ Andrzej MaryniarczyK, „Prawda o stworzeniu świata”, Nasz Dziennik, 6.12.2017.

${ }^{6}$ Słowa te św. Tomasz umieścił w tytule rozdziału 74 Sumy Contra Gentiles.
} 
dygmatyczne" rozumienie. Na jakiej jednak podstawie można uznać, że dana interpretacja jest „właściwa” i że stanowi obowiązujący paradygmat w danej dziedzinie wiedzy? Z filozofii nauki wiadomo, że nie ma prostej odpowiedzi na to pytanie, gdyż jest to złożony i wieloaspektowy problem ${ }^{7}$, a jego dokładna analiza znacznie wykraczałaby poza ramy tego opracowania. W tym miejscu warto zatem zawęzić to zagadnienie jedynie do teologii, a w ramach samej teologii ograniczyć się tylko do jednej koncepcji, którą jest kreacjonizm. Jak wiadomo, koncepcja ta ma wiele różnych interpretacji. Która z nich jest „właściwa”? To samo pytanie można również postawić inaczej: na jakiej podstawie teolog może własną interpretację tej koncepcji uznać za „właściwą", a wszystkie inne za „niewłaściwe"»? Autor niniejszego opracowania nie rości sobie prawa do tego, by ferować wyroki w tej sprawie, a także by udzielać jednoznacznych i rozstrzygających odpowiedzi na te pytania. Wypowiedziane tu uwagi odnoszą się bowiem również do niego samego - on też opowiada się przecież za jakąś interpretacją kreacjonizmu (jest zwolennikiem kreacjonizmu ewolucyjnego), a jeśli tak, to znaczy, że z jakichś względów właśnie tę interpretację uważa za bardziej adekwatną i lepiej uzasadnioną niż inne. Wydaje się jednak, że jest istotna różnica pomiędzy poszukiwaniem i przedstawianiem różnych argumentów uzasadniających daną interpretację kreacjonizmu a arbitralnym zadeklarowaniem, że jedna $\mathrm{z}$ tych interpretacji jest „właściwa”, ponieważ uzasadnia ją spójność określonego systemu filozoficznego, w ramach którego została sformułowana.

Sytuacja w teologii przypomina poniekąd to, co dzieje się w naukach przyrodniczych, gdzie określona teoria staje się paradygmatem nie dlatego, że jej autor uważa ją za „właściwą” teorię, ale dlatego, że ona sama „lepiej się broni" - w tym sensie, że jest lepiej uzasadniona i lepiej empirycznie potwierdzona niż wszystkie inne, alternatywne teorie ${ }^{9}$. „Empiryczne potwierdzenie" $\mathrm{z}$ oczywistych względów $\mathrm{w}$ teologii nie wchodzi $\mathrm{w}$ grę; nic jednak nie stoi na przeszkodzie, by przyjąć, że paradygmatyczną interpretacją kreacjonizmu jest ta, która (analogicznie do teorii fizycznych) sama „lepiej się broni" siłą uzasadniających ją argumentów, a nie jedynie spójnością określonego systemu pojęć. Zawsze bowiem istnieje ryzyko, że system

\footnotetext{
${ }^{7}$ Por. np. Andrzej Bronk, Monika Walczak, „Metoda naukowa”, w: JANEcZeK et AL., Metodologia nauk, 1:89-153; Anna LemańsKa, „Wyjaśnianie w nauce”, w: JANECZEK ET AL., Metodologia nauk, 1:231-249.

${ }^{8}$ Por. np. Andrzej Bronk, Stanisław MaJdAŃSKI, „Metodologia teologii”, w: JANECZEK ET AL., Metodologia nauk, 2:127-159; Tomasz WĘCŁAWSKI, „Metodologia teologii”, Nauka 3 (2004): 101-120.

${ }^{9}$ Por. Karl R. POPPER, Logika odkrycia naukowego, tłum. Urszula Niklas (Warszawa: PWN, 1977); Zygmunt HAJDUK, O akceptacji teorii empirycznej (Lublin: Wydawnictwo KUL, 1984).
} 
ten - choć przez długi czas wystarczał do nadawania adekwatnej interpretacji koncepcjom teologicznym — przestanie dobrze spełniać swoją funkcję, choćby ze względu na zmianę obrazu świata, spowodowaną rozwojem biologii i innych nauk przyrodniczych.

Autorzy opowiadający się za kreacjonizmem „tradycyjnym”" — którzy nie widzą możliwości uzgodnienia teologicznej prawdy o stwórczym działaniu Boga $\mathrm{w}$ przyrodzie $\mathrm{z}$ teorią ewolucji — znajdują swoich sprzymierzeńców $\mathrm{w}$ gronie zwolenników tzw. teorii inteligentnego projektu, o której będzie mowa w następnej części artykułu. Oczywiście, obydwie te interpretacje różnią się zasadniczo - i dlatego wzmianka o „sprzymierzeńcach” może w tym kontekście wydawać się sporą przesadą - ale przynajmniej w dwóch aspektach są do siebie podobne: obydwie są doktrynami religijnymi ${ }^{11}$ zakładającymi, że to Bóg jest stwórcą świata przyrody ${ }^{12}$, i obydwie kwestionują teorię ewolucji. Gdy idzie o kreacjonizm tradycyjny w wersji ,antyewolucyjnej”, to jego przedstawiciele uzasadniają konieczność zakwestionowania tej teorii m.in. tym, że ewolucjonizm to „ideologia ateistyczna"13, i dlatego nie da się go pogodzić z teologiczną prawdą o stworzeniu świata przez Boga. Ten argument wydaje się w sposób całkowicie nieuprawniony pomijać zasadniczą różnicę, jaka zachodzi pomiędzy teorią (taką jak teoria ewolucji) a jej interpretacją, która może (ale wcale nie musi być interpretacją ateistyczną) ${ }^{14}$.

Inny powód zakwestionowania teorii ewolucji — argument ten pojawił się już w cytowanej wcześniej wypowiedzi przedstawiciela kreacjonizmu tradycyjnego, ale występuje on również często u zwolenników inteligentnego projektu ${ }^{15}$ - ma związek z tym, że teoria ta oparta jest na przypadku,

\footnotetext{
${ }^{10}$ Pod tym określeniem będę rozumiał kreacjonizm (doktrynę głoszącą, że Bóg jest stwórcą świata) ujęty przy wykorzystaniu pojęć i koncepcji tradycyjnej metafizyki - której przedstawicielem jest np. św. Tomasz.

${ }^{11}$ Argumenty za tym, że ID jest w rzeczywistości doktryną religijną, zostaną przedstawione w dalszej części artykułu.

${ }^{12}$ Nawet jeśli niektórzy zwolennicy ID nie wypowiadają się w sprawie „twórcy” projektu, to i tak ich argumentacja oparta jest na założeniu, że sam Projektant nie mógł się pojawić we wszechświecie w wyniku działania praw przyrody - a zatem ma On charakter bytu nadprzyrodzonego. Ten sam argument pojawia się w uzasadnieniu wyroku sądowego z roku 2005 (będzie o nim mowa w dalszej części artykułu) dotyczącego rozstrzygnięcia kwestii, czy ID jest teorią naukową czy doktryną religijną.

${ }^{13}$ MaryniarcZyK, Prawda o stworzeniu świata, 14.

${ }^{14} \mathrm{O}$ tym, że istnieje taka różnica, i że teologowi nie wolno jej nie dostrzegać, pisał Jan Paweł II w przesłaniu z 22 października 1996 r. skierowanym do Papieskiej Akademii Nauk, zob. JAN PAwEe II, „Magisterium Kościoła wobec ewolucji”, L'Osservatore Romano 18, nr 1 (1997): 18-19.

${ }^{15} \mathrm{~W}$ sensie ścisłym, zwolennicy ID nie głoszą wprost, że ewolucja oparta na przypadku to „negacja prawdy o stworzeniu” (MARYNIARCZYK, Prawda o stworzeniu świata, 14), lecz że przy-
} 
którego rzekomo nie da się pogodzić z ideą stworzenia świata przez Boga. Leżące u podstaw tego argumentu założenie, że Stwórca nie może posługiwać się zdarzeniami przypadkowymi, jest jednak poważnym błędem teologicznym, który na dodatek jawi się jako współczesna forma starej herezji, jaką był manicheizm - starożytna koncepcja głosząca, że Bóg nie jest suwerennym władcą wszechświata, bo istnieje równy $\mathrm{Mu}$ (pod względem mocy) przeciwnik, z którym musi On nieustannie konkurować ${ }^{16} . \mathrm{Z}$ teologicznego punktu widzenia nie ma żadnych podstaw do tego, by zdarzenia przypadkowe, wkomponowane $\mathrm{w}$ strukturę wszechświata rządzonego matematycznymi prawami przyrody, wyłączać z całego arsenału środków, którymi może posługiwać się Stwórca powołujący do istnienia organizmy i struktury świata nieożywionego. Przypadek nie jest zatem czymś, co wymyka się Bogu spod kontroli i z czym musi On konkurować, ustalając jednoznacznie przebieg wszystkich zdarzeń składających się na historię stworzonego świata ${ }^{17}$. Całkowicie bezpodstawne jest więc przeciwstawianie zdarzeń przypadkowych działaniom Stwórcy powołującego do istnienia świat przyrody, dlatego że „Bóg jest także Panem przypadków”"

\section{INTELIGENTNY PROJEKT}

Pomijając dalszą dyskusję z kreacjonizmem tradycyjnym w wersji ,,antyewolucyjnej”, warto w tym miejscu nieco więcej uwagi poświęcić teorii inteligentnego projektu ${ }^{19}$ (określanej również skrótem ID — od angielskiego

padkiem nie da się wytłumaczyć nieredukowalnej złożoności świata przyrody.

${ }^{16}$ Port. Michał Heller, Filozofia przypadku. Kosmiczna fuga z preludium i coda (Kraków: Copernicus Center Press, 2011), 141-147.

${ }^{17}$ Por. Michał Heller, Tadeusz Pabjan, Stworzenie i początek wszechświata. Teologia filozofia - kosmologia (Kraków: Copernicus Center Press, 2013), 134-143; Józef Zon, „Nic nowego w starym sporze", Filozoficzne Aspekty Genezy 23 (2005/2006): 25-33.

${ }^{18}$ „W teologii chrześcijańskiej nie jest tak, że istnieje Bóg i niezależny od niego materialny świat; świat stawia Bogu opór i Bóg na nim niejako wymusza swoją wolę. A właśnie taki obraz zakłada teza głosząca, że Bóg eliminuje przypadki przy pomocy swojego «inteligentnego projektu». Wszechświat to nie tylko «budulec» odpowiednio poukładany i odpowiednio funkcjonujący. Wszechświat to przede wszystkim układ praw przyrody, działających również przy pomocy strategii przypadków. I prawa przyrody, i przypadki są elementami kompozycji, którą nazywamy Dziełem Stworzenia. Przypadki, tak samo jak prawa przyrody, są istotnymi składnikami tego Dzieła. Bóg jest także Panem przypadków"; Michał Heller, Przedmowa do trzeciego wydania polskiego, w: Ernan McMullin, Ewolucja i stworzenie, tłum. Jacek Rodzeń (Tarnów: Biblos, 2006), xiii.

${ }^{19}$ Argumenty formułowane w ramach teorii ID można znaleźć np. w Michael J. BEHE, Darwin's Black Box: The Biochemical Challenge for Evolution (New York: Free Press, 1996); 
Intelligent Design), która z nieco innych powodów, i w nieco inny sposób, kwestionuje teorię ewolucji - nie odrzuca jej w całości, dopatrując się w niej ,ideologii ateistycznej”, ale wskazuje na to, że jest to teoria w pewnym sensie niezupełna, bo nie dostarcza adekwatnego i satysfakcjonującego wyjaśnienia procesów ewolucyjnych. Podstawowy (choć oczywiście nie jedyny) argument zwolenników ID jest następujący: teoria ewolucji nie potrafi wyjaśnić subtelnej złożoności organizmów żywych (w tym kontekście przedstawiciele ID mówią o „nieredukowalnej złożoności organizmów”20), i dlatego należy przyjąć, że organizmy musiały zostać bezpośrednio zaprojektowane przez Inteligentnego Projektanta. Kim jest ów Projektant? Pytanie to jest $\mathrm{w}$ rzeczywistości pytaniem o charakter teorii inteligentnego projektu, czyli o to, czy jest to teoria naukowa ${ }^{21}$, czy doktryna religijna. W tej kwestii zdania są podzielone.

Zwolennicy ID sądzą, że jest to teoria naukowa, a świadczy o tym - ich zdaniem-przede wszystkim to, że argumenty za obecnością Projektanta są tu formułowane na płaszczyźnie ściśle naukowej: znaczna część każdej publikacji z zakresu tej teorii to obszerne, szczegółowe analizy różnego rodzaju organów, układów biologicznych i szczegółów anatomicznych roślin i zwierząt, które nie mogły powstać na skutek działania „zwykłych” mechanizmów ewolucyjnych - takich jak przypadkowe mutacje i dobór naturalny — ale musiały zostać zaprojektowane przez Inteligentnego Projektanta. Inny rodzaj podobnych argumentów odwołujących się do danych zaczerpniętych z biologii ewolucyjnej dotyczy mikroewolucji (zmiany dokonujące się w obrębie gatunków) i makroewolucji (zmiany prowadzące do powstawania nowych gatunków). Zwolennicy ID twierdzą, że w obrębie nauk przyrodniczych nie udaje się wyjaśnić powstawania wielkiej złożoności budowy i funkcji organizmów, obejmującej wyższe niż gatunek kategorie taksonomiczne, i w związku z tym należy przyjąć, iż pierwszy przedstawiciel każdego nowego gatunku został zaprojektowany. Jest to naukowy dowód na obecność Projektanta (a więc

William A. Dembski, Intelligent Design. The Bridge between Science and Theology (Downers Grove, IL: InterVarsity Press, 1999); Teoria Inteligentnego Projektu - nowe rozumienie naukowości?, red. Kazimierz Jodkowski (Warszawa: Megas, 2007).

${ }^{20}$ Por. Michael J. BeHE, „Irreducible Complexity: Obstacle to Darwinian Evolution”, w: Debating Design: From Darwin to DNA, red. Michael Ruse, William A. Dembski (Cambridge: CUP, 2004), 352-370.

${ }^{21}$ Pod określeniem „teoria naukowa” będę w tym artykule rozumiał teorię nauk empirycznych. To zastrzeżenie jest o tyle istotne, że - ze względu na to, iż filozofia i teologia też są naukami — nic nie stoi na przeszkodzie, by różnego rodzaju koncepcje filozoficzne i teologiczne również określać mianem „teorii naukowych”. 
również sama teoria ID jest teorią naukową) ponieważ jego istnienie zostało w tym przypadku wykazane na płaszczyźnie nauk przyrodniczych.

Jeśli jednak ID jest teorią naukową, to kim jest Projektant? Odpowiedź sugerująca, że zadaniem teorii ID nie jest ustalenie tożsamości Projektanta, ale samo dowodzenie jego obecności, nie wydaje się specjalnie przekonująca. O wiele bardziej przekonujące jest to, że teoria inteligentnego projektu jest $\mathrm{w}$ rzeczywistości zawoalowaną doktryną religijną, która próbuje znaleźć naukowe dowody na stwórcze działanie Boga, nazwanego tu Inteligentnym Projektantem $\mathrm{z}$ tego powodu, by właśnie takiemu wyjaśnieniu nadać pozory teorii ściśle naukowej. Mocnym argumentem przemawiającym za słusznością tego wyjaśnienia jest również historyczny kontekst powstania teorii ID ${ }^{22}$.

Jak wiadomo, teoria ta wywodzi się z tradycji tzw. kreacjonizmu „,naukowego", który pojawił się na początku XX wieku w kręgu amerykańskich fundamentalistów religijnych ${ }^{23}$. Choć niektórzy z twórców tego kierunku sprzyjali ideom ewolucyjnym, to jednak z czasem — szczególnie na gruncie amerykańskim - zaczęły w nim przeważać poglądy antyewolucyjne, które wkrótce dały początek kreacjonizmowi „naukowemu”. Była to koncepcja teologiczna oparta na dosłownym rozumieniu biblijnego opisu stworzenia, która zarazem rościła sobie prawo do uchodzenia za teorię naukową, stanowiącą swego rodzaju alternatywę wobec teorii ewolucji. Nie bez znaczenia było w tym przypadku to, że chodziło tu również o możliwość nauczania w szkołach tak pojmowanego kreacjonizmu jako teorii naukowej. Gdy sprawa oparła się o sąd, i gdy w kilku stanach USA różne instancje sądowe orze$\mathrm{kły}^{24}$, że kreacjonizm jednak nie jest teorią naukową, ale doktryną religijną - i w związku z tym nie można go nauczać w szkołach, ponieważ zabrania tego Pierwsza Poprawka do amerykańskiej konstytucji — pojawiła

\footnotetext{
${ }^{22}$ Por. Ronald L. Numbers, „The Creationists”, w: Lindberg, Numbers, God and Nature, 391-423; Nicolas MAtzKe, „The Evolution of Creationist Movements”, Evolution Education and Outreach 3, nr 2 (2010): 145-162; Heller, Filozofia przypadku, 133-140.

${ }^{23}$ Określenie „fundamentalizm” pojawiło się w związku z cyklem konferencji zorganizowanych w latach 1878-1897 w USA przez kościoły protestanckie, których celem było ustalenie, które prawdy sa „fundamentalne” dla wiary chrześcijańskiej. Prawdy te zostały opracowane (i opublikowane w latach 1910-1915) w liczącym kilkanaście obszernych tomów wydawnictwie The Fundamentals.

${ }^{24}$ W roku 1987 tą sprawą zajmował się nawet Sąd Najwyższy Stanów Zjednoczonych. Na temat przebiegu procesów, w których to sędziowie mieli rozstrzygnąć o tym, czy kreacjonizm jest teorią naukową (było to tzw. „małpie procesy”), por. np. Heller, Filozofia przypadku, 134-137; Kazimierz JodKowski, „Kreacjoniści przed sądem. Aspekty filozoficzne «małpich procesów»”, w: Poszukiwania filozoficzne, red. Jakub Michalczenia, Jadwiga Mizińska, Katarzyna Ossowska, t. 1, Nauka, Prawda (Olsztyn: Instytut Filozofii UWM, 2014), 175-198.
} 
się potrzeba takiego przeformułowania kreacjonizmu „naukowego”, by nadal można było utrzymywać, iż w rzeczywistości jest on teorią naukową, i że stanowi poważną alternatywę wobec teorii ewolucji.

$\mathrm{W}$ ten sposób zrodziła się teoria inteligentnego projektu, która wprost nie odwołuje się do obecności Boga, ale mówi o Inteligentnym Projektancie, mającym istotny udział $\mathrm{w}$ procesie ewolucji życia, a w szczególności w powstawaniu „nieredukowalnie złożonych” organizmów. Czy jednak rzeczywiście samo zastąpienie słowa „Bóg” określeniem „Inteligentny Projektant” i przesunięcie akcentów w narracji dotyczącej teorii ewolucji wystarczają do tego, by doktryna religijna stała się koncepcją naukową? Z pewnością nie. Co ciekawe, jak podkreślił wyraźnie jeden z sędziów (John E. Jones), który w roku 2005 musiał rozstrzygnąć (podobnie jak kilkadziesiąt lat wcześniej jego koledzy zajmujący się kreacjonizmem „naukowym”) czy teoria ID jest koncepcją naukową czy też nie. Jednoznaczna ocena tej teorii została przez niego zawarta już $\mathrm{w}$ samym tytule jednego z rozdziałów werdyktu, który brzmi: „Obiektywny obserwator zauważy, że Inteligentny Projekt (ID) i nauczanie o «lukach» $\mathrm{i}$ «problemach»w teorii ewolucji są religijnymi, kreacjonistycznymi strategiami, które wyewoluowały z wcześniejszych postaci kreacjonizmu" 25 . W samym zaś uzasadnieniu werdyktu pojawiają się następujące, jednoznaczne sformułowania: ,religijna natura ID jest oczywista, ponieważ koncepcja ta zakłada istnienie nadnaturalnego projektanta. [...] Eksperci powołani przez zwolenników ID potwierdzili, że istnienie nadnaturalnego projektanta jest nieodłącznym atrybutem ID"26.

Czy zatem ID rzeczywiście jest teorią naukową? Pomijając wszystkie inne, znane z ogólnej metodologii nauk, kryteria „naukowości”, warto w tym miejscu zwrócić uwagę, że teoria ID nie spełnia podstawowego kryterium, bez którego trudno traktować daną koncepcję jako teorię nauk ścisłych. Jest nim naturalizm metodologiczny, który domaga się tego, by w procesie wyjaśniania świata przyrody naukowiec-empiryk nie odwoływał się do żadnych zewnętrznych (względem tego świata) czynników. Inteligentny Projektant, o którym mówi teoria ID — zwraca na to uwagę cytowany powyżej werdykt sędziego Jonesa - jest właśnie tego typu „czynnikiem”. Ujawnia się tu istotny brak konsekwencji teorii inteligentnego projektu: chce ona uchodzić za teorię naukową, ale zarazem nie respektuje reguł stojących na straży me-

\footnotetext{
${ }^{25}$ Kitzmiller vs. Dover Area School District, 400 F. Supp. 2d 707 (M.D. Pa. 2005); uzasadnienie wyroku można znaleźć na stronie https://law.justia.com/cases/federal/district-courts/ FSupp2/ 400/707/2414073/ (dostęp 20.02.2020).

${ }^{26}$ Tamże.
} 
todologicznej poprawności nauk przyrodniczych. Leżąca u podstaw tej teorii argumentacja jest też nieprzekonująca $\mathrm{z}$ tego powodu, że można jej łatwo zarzucić tzw. błąd alternatywnego wyjaśniania. Bo nawet jeśli rzeczywiście byłoby tak, że teoria ewolucji nie daje satysfakcjonującego wyjaśnienia jakiegoś aspektu procesów ewolucyjnych (samego pojawienia się życia na Ziemi, powstawania nowych gatunków, nieredukowalnej złożoności organizmów itp.), to i tak wierność metodologii nauk przyrodniczych domagałaby się $\mathrm{w}$ takim przypadku dalszego rozwijania i doskonalenia teorii - $\mathrm{w}$ taki sposób, by umożliwiła ona znalezienie lepszego, bardziej adekwatnego wyjaśnienia tych procesów. Metodologicznym błędem byłoby w tym przypadku przyjęcie, że jedyna alternatywą wobec teorii ewolucji jest istnienie inteligentnego projektanta. Byłby to zarazem błąd logiczny polegający na nieuprawnionym przejściu od przesłanki (o niewystarczalności wyjaśnień dostarczanych przez teorię ewolucji) do wniosku (o istnieniu projektanta) w rozumowaniu leżącym u podstaw teorii ID $^{27}$.

Trudno nie dostrzec także wyraźnego podobieństwa - a może nawet czegoś więcej niż zwykłe podobieństwo - pomiędzy argumentacją teorii inteligentnego projektu i metodą wyjaśniania świata przyrody, którą w przeszłości preferowali przedstawicieli tzw. fizykoteologii ${ }^{28}$. Metoda ta w praktyce sprowadza się do traktowania Boga jako „zapchajdziury” (God of gaps) wypełniającej luki w naukowej wiedzy o świecie przyrody ${ }^{29}$. To, czego nie potrafią wytłumaczyć nauki przyrodnicze, przypisuje się tu bezpośredniemu działaniu Stwórcy, a samą niewystarczalność wyjaśnień dostarczanych przez nauki ścisłe traktuje się $\mathrm{w}$ kategoriach naukowego dowodu na obecność Boga w przyrodzie. Nie ulega żadnej wątpliwości, że takie „wyjaśnianie” z kilku różnych względów należy ocenić w sposób jednoznacznie negatywny. Przede wszystkim chodzi tu o teologiczne błędy tego typu „metodologii” (świat stworzony przez Boga jest tu dziełem niedoskonałym, które domaga się nieustannych poprawek i bezpośrednich ingerencji Stwórcy, umożliwiających normalne funkcjonowanie przyrody) oraz o wyjątkową krótkowzroczność tych, którzy się nią posługują. Z upływem czasu bowiem rozwijające się nauki stopniowo same wypełniają „dziury” w wiedzy o świecie, co oznacza, że hipoteza Boga staje się niepotrzebna, a samo wyjaśnienie — które z założenia miało dostarczyć naukowego dowodu na istnienie Stwórcy -

\footnotetext{
${ }^{27}$ Por. PaBJan, Anatomia konfliktu, 98-104.

${ }^{28} \mathrm{Na}$ temat historii tej koncepcji por. np. McMullin, Ewolucja i stworzenie, 53-75.

${ }^{29}$ Por. Marek SŁomKA, Działanie Boga $w$ przyrodzie. Analiza filozoficzna (Lublin: Wydawnictwo KUL, 2018), 205-214.
} 
staje się argumentem na rzecz ateizmu ${ }^{30} . \mathrm{W}$ tym kontekście warto zauważyć, że tzw. brakujące ogniwa, nieredukowalna złożoność albo mechanizm odpowiedzialny za makroewolucję, traktowane są przez przedstawicieli ID właśnie jako dziury w naukowej wiedzy o świecie, których teoria ewolucji nie jest w stanie wypełnić wystarczająco przekonującym wyjaśnieniem. Nawet jeśli argument ten byłby słuszny (a $\mathrm{z}$ tym z pewnością nie zgodziłoby się wielu biologów i przedstawicieli innych nauk przyrodniczych, zajmujących się np. samoorganizacją struktur w stanach odległych od równowagi termodynamicznej), to wyjaśnienie proponowane przez ID jest niczym innym jak właśnie „włożeniem” Boga - Inteligentnego Projektanta — do tych dziur.

To, czy w teorii ewolucji rzeczywiście znajdują się „dziury” - czy wyjaśnienie procesów ewolucyjnych dostarczane przez tę teorię faktycznie jest adekwatne i zadowalające-zawsze może być przedmiotem dyskusji, w której powinni być zaangażowani przede wszystkim kompetentni przedstawiciele nauk przyrodniczych. Z historii ogólnej metodologii nauk (problem falsyfikacji teorii) wiadomo jednak, że nie jest uzasadnione kwestionowanie jakieś teorii z tego jedynie powodu, że znajdują się w niej „dziury” np. że nie dostarcza ona dobrego wyjaśnienia jakiegoś fenomenu albo procesu. Same „dziury” nie są wystarczającym powodem do tego, by taką teorię w całości odrzucić, dlatego że zazwyczaj dobrze tłumaczy ona szereg innych zjawisk albo procesów w danej dziedzinie ${ }^{31}$. Praktyka badawcza, potwierdzona przez liczne przykłady znane $\mathrm{z}$ historii nauki ${ }^{32}$, jest właśnie taka: nie odrzuca się „starej” teorii — nawet jeśli są w niej „dziury” — dopóki nie będzie lepszej, bardziej ogólnej, „nowej” teorii, która wyjaśni to, czego nie potrafiła wytłumaczyć „stara” teoria. Wypełnianie „dziury” bezpośrednim działaniem Boga byłoby w takim przypadku niczym nieuzasadnioną rezygnacją z fundamentalnej zasady metodologicznej, która domaga się, by wobec zaistniałej trudności poszukiwać lepszej, bardziej ogólnej teorii, i w taki sposób rozwijać metodę naukową, aby rozwiązać problem bez odwoływania się do nadzwyczajnych ingerencji Stwórcy.

\footnotetext{
${ }^{30}$ Heller trafnie zauważa, że jeszcze bardziej niebezpieczne jest to, że idea „Boga od dziur” jest zakłamaniem teologicznej prawdy o Stwórcy: „Nie idzie tu o obronną strategię: bo potem rozwój nauki i hipoteza Boga staje się zbyteczna, lecz o kwestię teologicznej prawdy. Bóg, który ma wypełnić braki naszej wiedzy o świecie, jest po prostu teologicznym fałszem"; Michał HELLER, Józef Życiński, Dylematy ewolucji (Kraków: PTT, 1990), 147.

${ }^{31}$ Por. Imre LAKATOS, „Falsyfikacja a metodologia naukowych programów badawczych”, w: Imre Lakatos, Pisma z filozofii nauk empirycznych, thum. Wojciech Sady (Warszawa: PWN, 1995), 3-169.

${ }^{32}$ Dobrym przykładem jest problem ruchu peryhelionowego Merkurego, którego nie potrafiła wyjaśnić mechanika klasyczna. Wyjaśnienie to dostarczyła dopiero ogólna teoria względności.
} 
Nie bez znaczenia jest w tym przypadku również i to, że wypełnianie rzekomej czy faktycznej „dziury” bezpośrednim działaniem Boga — Inteligentnego Projektanta - w zasadniczy sposób komplikuje (i tak już niełatwą) sytuację w teodycei, która próbuje zdjąć ze Stwórcy odpowiedzialność za zło obecne w świecie. Skoro to Bóg projektuje organizmy żywe, to znaczy, że liczne przejawy zła fizycznego dostrzegane w przyrodzie (m.in. cierpienie towarzyszące niezawinionym chorobom, kalectwu i różnym formom niedorozwoju fizycznego i umysłowego, okrucieństwo wynikające $\mathrm{z}$ brutalnej walki zwierząt o przetrwanie, albo różnego rodzaju dysfunkcje, wady i niedoskonałości organizmów) są bezpośrednią konsekwencją Jego projektu ${ }^{33}$. Odpowiedzialność za zło jest w tym przypadku o wiele większa niż wtedy, gdy zakłada się - o czym będzie mowa w następnym paragrafie - że Stwórca konsekwentnie respektuje autonomię świata przyrody. W tej ostatniej interpretacji zło fizyczne jawi się jako cena tej autonomii - na tej samej zasadzie, jak zło moralne (grzech) jest ceną wolności darowanej człowiekowi.

\section{BÓG DZIAŁAJĄCY ZA POŚREDNICTWEM PRZYCZYN WTÓRNYCH}

Nie ma wielkiej przesady w stwierdzeniu, że spór o interpretację tego, w jaki sposób należy rozumieć stwórcze działanie Boga w przyrodzie, toczył się $\mathrm{w}$ teologii chrześcijańskiej od zawsze - w tym sensie, że już pierwsi Ojcowie Kościoła, a po nich teologowie i filozofowie średniowiecza i kolejnych epok ery nowożytnej, dyskutowali nad problematyką stworzenia ${ }^{34}$. Ta dyskusja trwa nieprzerwanie do dziś. Jej owocem jest wypracowanie pewnych pojęć i koncepcji, które we współczesnej teologii traktowane są w kategoriach swego rodzaju ,interpretacyjnego paradygmatu” oddającego teologiczną prawdę o stwórczym działaniu Boga w świecie przyrody. Do tego

\footnotetext{
${ }^{33}$ Por. Tadeusz PabJan, Świat najlepszy z możliwych? O dobroci Boga i pochodzeniu zła (Kraków: Copernicus Center Press, 2018), 127-162.

${ }^{34}$ Por. np. David C. LindBerg, „Science in the Early Church”, w: God and Nature: Historical Essays on the Encounter between Christianity and Science, red. David C. Lindberg, Ronald L. Numbers (Berkeley: University of California Press, 1986), 19-48; Grant, „Science and theology in the Middle Ages”, w: Lindberg, Numbers, God and Nature, 49-75; James R. Moore, „Geologists and Interpreters of Genesis in the Nineteenth Century", w: LindBerG, NumBers, God and Nature, 322-350; A. Hunter DupreE, „Christianity and the Scientific Community in the Age of Darwin”, w: LindBerg, NumBers, God and Nature, 351-368.
} 
typu koncepcji należy zaliczyć przede wszystkim doktrynę ciągłego stwarzania (creatio continua), zgodnie z którą stworzenie nie jest jednorazowym, zakończonym aktem mającym miejsce na początku ${ }^{35}$ historii świata, ale jest nieustannie trwającym „dawaniem istnienia”, rozciągniętym w czasie na całą historię tego co stworzone; oraz ideę Bożej immanencji, która mówi o nieustannej obecności Stwórcy $\mathrm{w}$ świecie przyrody ${ }^{36}$. Teologiczną prawdę o stworzeniu dobrze oddają również filozoficzne pojęcia i rozróżnienia wykorzystywane przez św. Tomasza — zwłaszcza rozróżnienie na byt samoistny, który w samym sobie ma rację swego istnienia, oraz byt przygodny, który swoje istnienie otrzymuje od bytu samoistnego. Stworzenie to nic innego jak relacja lub zależność. Co istotne, nie jest to zależność o charakterze fizykalnym, ale ontycznym - pomiędzy Bogiem, który jest bytem samoistnym, a światem, który jest bytem przygodnym. W podobnym duchu utrzymane jest inne rozróżnienie: na przyczynę pierwszą, która uzdalnia do działania wszystkie inne przyczyny, oraz przyczyny wtórne, które działają mocą przyczyny pierwszej. Przyczyną pierwszą jest Bóg, a przyczynami wtórnymi są wszystkie byty stworzone, które w świecie przyrody ${ }^{37}$ są włączone w łańcuchy ciągów przyczynowo-skutkowych tworzących historie poszczególnych struktur, układów i organizmów.

Te rozróżnienia pozwoliły św. Tomaszowi doprecyzować interpretację tego, jak należy rozumieć działanie Boga w świecie przyrody. Polemizując $\mathrm{z}$ poglądem, który współcześnie określany jest mianem okazjonalizmu, Akwinata wielokrotnie podkreślał, że choć w świecie przyrody Stwórca mógłby działać bezpośrednio jako przyczyna pierwsza, to jednak Jego działanie dokonuje się zawsze za pośrednictwem przyczyn wtórnych. Bóg mógłby działać sam, bez żadnego pośrednictwa, ale tego nie czyni z następujących powodów: „po pierwsze dlatego, że przez to zostałby zniesiony w rzeczach stworzonych porządek: przyczyna - skutek, a to świadczyłoby o niemocy Stworzyciela; a przecież potęga działającego sprawia, że swojemu skutkowi daje moc do działania. Po drugie, że — znajdujące się w rzeczach siły dzia-

\footnotetext{
${ }^{35}$ Już św. Tomasz wykazał (w dziele De aeternitate mundi), że można sensownie mówić o stworzeniu świata istniejącego odwiecznie, tzn. niemającego początku w czasie, por. Heller, PaBjan, Stworzenie i początek wszechświata, 67-88.

${ }^{36} \mathrm{~W}$ tym kontekście mówi się niekiedy o tzw. panenteizmie, por. np. Józef ŻYCIŃsKI, Bóg i ewolucja. Podstawowe pytania ewolucjonizmu chrześcijańskiego (Lublin: Towarzystwo Naukowe KUL, 2002), 132-144.

${ }^{37}$ Do przyczyn wtórnych, działających mocą przyczyny pierwszej, należy również zaliczyć przyczyny działające w świecie duchowym.
} 
łające na darmo byłyby dane rzeczom, gdyby przez nie niczego nie dokonywały. Co więcej, wszystkie stworzone rzeczy wydawałyby się istnieć na darmo, gdyby zostały pozbawione właściwego im działania, gdyż każda rzecz istnieje dla swojego działania" ${ }^{38}$. W innym miejscu św. Tomasz wyjaśnia, że właśnie taki sposób działania Boga w świecie przyrody świadczy o Jego miłości i szacunku do stworzeń, które w zamyśle Stwórcy mają mieć realną autonomię - co oznacza, że mają być również obdarzone własną, autentyczną przyczynowością: „opatrzność Boska posługuje się pośrednikami i z zasady rzeczami niższymi rządzi za pomocą wyższych. Nie z powodu słabości swoich sił, ale z obfitości swej dobroci, bo chce, by i stworzenia dzieliły z nim godność przyczyny" ${ }^{\prime 3}$.

Jeśli pamięta się o tym, że Bóg - jako przyczyna pierwsza - uzdalnia do istnienia i działania wszystkie przyczyny wtórne, i że jest w tych przyczynach immanentnie obecny, to staje się jasne, iż nie musi On w żaden sposób konkurować z procesami fizycznymi, chemicznymi i biologicznymi (nawet jeśli są oparte na zdarzeniach przypadkowych!), które w interpretacji filozoficznej jawią się właśnie jako ciągi przyczyn wtórnych. Nie musi naruszać autonomii stworzeń i odbierać im „godności przyczyny”, by uzyskać zamierzony przez siebie efekt. Nie musi działać bezpośrednio jako przyczyna pierwsza, bo jest immanentnie obecny w przyczynach wtórnych i działa za ich pośrednictwem ${ }^{40}$. Warto $\mathrm{w}$ tym miejscu zwrócić uwagę, że teoria inteligentnego projektu sprowadza się w rzeczywistości do zakwestionowania słuszności tej interpretacji: Bóg nie może-twierdzą zwolennicy ID—powołać do istnienia organizmów nieredukowalnie złożonych posługując się „zwykłymi”, przypadkowymi procesami ewolucyjnymi (przyczynami wtórnymi); Bóg może stworzyć te organizmy jedynie na drodze działania bezpośredniego (w charakterze przyczyny pierwszej), polegającego na „zaprojektowaniu” ich struktury. Powyższy argument, odwołujący się do filozoficznego rozróżnienia wykorzystywanego przez św. Tomasza, zapewne nie przekona wyznawców ID, którzy traktują swoją koncepcję w kategoriach teorii naukowej, i którzy na poparcie tezy o niewystarczalności teorii ewolucji wolą przywoływać racje $z$ biologii i innych nauk przyrodniczych, a nie z filozofii. Dziwne jednak, że nie dostrzegają siły tego argumentu ci teologowie, którzy na swoich sztandarach mają filozofię św. Tomasza,

${ }^{38}$ Św. Tomasz, Suma teologiczna, I q. 105 a. 5, thum. Pius Bełch i in., t. 8, Rządy Boże (London: Veritas, 1963-1986), 43.

${ }^{39}$ Św. Tomasz, Suma teologiczna, I q. 22 a. 3 (t. 2, O Bogu, 185).

${ }^{40}$ Por. PABJan, Anatomia konfliktu, 131-134. 
i w oparciu o jego poglądy dowodzą, że kreacjonizmu w żaden sposób nie da się pogodzić $\mathrm{z}$ ewolucją ${ }^{41}$.

Warto w tym kontekście zauważyć, że interpretacja Akwinaty wydaje się dobrze uzasadniać słuszność kreacjonizmu ewolucyjnego, który głosi, że stwórcze działanie Boga (pierwszej przyczyny) dokonuje się w świecie przyrody nie bezpośrednio, ale za pośrednictwem przyczyn wtórnych, to znaczy przyczyn o charakterze fizyko-chemicznym. Doktryna mówiąca o immanentnej obecności Boga w poszczególnych obiektach i strukturach świata przyrody - przede wszystkim zaś w podlegających ewolucji biologicznej organizmach żywych - a także koncepcja ciągłego stwarzania, z której wynika, że Stwórca nieustannie ,podtrzymuje” świat w istnieniu, i że akt stworzenia nie jest definitywnie zakończony, ale ciągle kontynuowany — to dodatkowe racje o charakterze teologicznym, przemawiające za spójnością tej interpretacji.

Przemawiają za tą spójnością również racje metodologiczne: kreacjonizm ewolucyjny nie jest teorią z zakresu nauk przyrodniczych, ale koncepcją teologiczno-filozoficzną. Nie jest zatem metodologicznym błędem to, gdy w ramach wyjaśnień o właśnie takim (teologiczno-filozoficznym) charakterze wskazuje się na Boga, który jest najgłębszym źródłem racjonalności przejawiającej się w prawach przyrody powodujących stopniowy rozwój całego wszechświata i ewolucję życia biologicznego. Problem pochodzenia praw przyrody nie jest bowiem zagadnieniem o charakterze ściśle naukowym (nie można go rozstrzygnąć na płaszczyźnie nauk przyrodniczych), ale filozoficznym, ewentualnie teologicznym. Metodologiczne reguły obowiązujące filozofa lub teologa nie są zatem naruszone wtedy, gdy w racjonalności praw przyrody powodujących ewolucję życia dostrzega on stwórcze działanie Boga. To samo wyjaśnienie traci jednak metodologiczną poprawność wtedy, gdy głosi się — jak czynią to zwolennicy ID — że działanie Stwórcy nie ogranicza się jedynie do ustalenia zestawu praw przyrody, ale polega na

\footnotetext{
${ }^{41}$ Powodów do tak radykalnego zanegowania ewolucji nie widział np. Krąpiec, który pisał: „Jeśli zatem istnieje ewolucja, jeśli istnieje rozwój, to istnieje współmierny czynnik warunkujący i «uniesprzeczniający» ten rozwój. Przyczyna Pierwsza i jej obecność (szczególnego rzędu) w świecie we wszystkich zjawiskach, we wszystkich procesach i stanach bytowych jest dostateczną racją bytu, uniesprzeczniającą fakty ewolucji. A fakty tak zwanej ewolucji darwinowskiej są naturalnym doborem stale dokonującym się w przyrodzie" - Mieczysław A. Krąipiec, „Ewolucjonizm, ale jaki?”, w: Ewolucjonizm czy kreacjonizm, red. Piotr Jaroszyński (Lublin: Fundacja Lubelska Szkoła Filozofii Chrześcijańskiej, 2008), 39. Na temat możliwości uzgodnienia teorii ewolucji z filozofią św. Tomasza por. np. Nicanor P. G. Austriaco i in., Ewolucja w świetle wiary. Perspektywa tomistyczna, tłum. Grażyna Gomola, Aleksander Gomola (Poznań: W drodze, 2019).
} 
bezpośrednim „projektowaniu” organizmów, odkrywanym i badanym przy pomocy metod empirycznych. W tym kontekście warto zauważyć, że kreacjonizm ewolucyjny różni się od teorii ID z pozoru nieznacznym - ale w rzeczywistości bardzo istotnym - przesunięciem akcentu $\mathrm{w}$ interpretacji słowa „projekt”, które w pewnym sensie zostało zawłaszczone ${ }^{42}$ przez koncepcję kwestionującą teorię ewolucji: w kreacjonizmie ewolucyjnym zakłada się, że projekt dokonuje się na poziomie praw przyrody; w teorii ID - na poziomie poszczególnych organizmów. Pierwsze wyjaśnienie ma charakter filozoficzno-teologiczny i dlatego - z racji wcześniej wspomnianych - nie narusza reguł metodologicznych, drugie uchodzi za wyjaśnienie naukowe i dlatego łamie zasadę naturalizmu metodologicznego, którą tego typu wyjaśnienie powinno respektować.

Spór o interpretację stwórczego działania Boga w świecie przyrody jest w dużej mierze sporem o to, w jaki sposób powinny układać się relacje między nauką i wiarą. Jak wiadomo, nigdy nie było pełnej zgody uczonych (zarówno naukowców-przyrodników jak i teologów) co do tego, czy istnieje realny i zarazem niemożliwy do usunięcia konflikt pomiędzy tymi dwoma dziedzinami. Z całej palety różnych stanowisk, które wykrystalizowały się w dyskusji nad tym zagadnieniem ${ }^{43}$, na szczególną uwagę zasługuje tu interpretacja głosząca, że konflikt jest fundamentalny i nie można go w żaden sposób uniknąć. O ile nie dziwi fakt, że zwolennikami tego stanowiska są ci naukowcy, którzy z racji światopoglądowych odrzucają wiarę religijną i nie traktują poważnie teologii, o tyle dziwić może to, że na tym stanowisku stają również sami teologowie i przedstawiciele filozofii chrześcijańskiej. Beztroska i łatwość, z jaką pozwalają sobie oni na kwestionowanie wyników nauk przyrodniczych, są w rzeczywistości utrwalaniem tezy o nieuniknionym konflikcie nauki i wiary, i dostarczaniem kolejnych argumentów tym, którzy cały Kościół katolicki — instytucję, której na zasadzie pars pro toto przypisuje się poglądy poszczególnych teologów - co najmniej od czasów Galileusza uważają za emanację obskurantyzmu i zagrożenie dla nauki. Jest to zarazem zerwanie $\mathrm{z}$ wielowiekową tradycją filozofii chrześcijańskiej,

\footnotetext{
${ }^{42}$ Por. Heller, Filozofia przypadku, 140.

${ }^{43}$ Por. Ian G. Barbour, „Ways of Relating Science and Theology”, w: Physics, Philosophy and Theology: A Common Quest for Understanding, red. Robert J. Russel, William Stoeger, George V. Coyne (Vaticano: Vatican Observatory Publications 1988), 21-48.
} 
która - począwszy od św. Augustyna, poprzez św. Anzelma i św. Tomasza, aż po św. Jana Pawła II - nakazywała zawsze uzgadniać (a nie przeciwstawiać sobie) rozum i wiarę.

Czy zatem opowiadanie się za kreacjonizmem ewolucyjnym rzeczywiście jest „rozdawaniem samochodów na Placu Czerwonym”44? I czy faktycznie „wyrasta z szantażu, że jeśli nie przyjmiemy ewolucjonizmu, to jesteśmy fanatykami religijnymi" "45? Czytelnik tego artykułu musi sam udzielić sobie odpowiedzi na te pytania - pamiętając o tym, co jest prawdziwą stawką sporu o stwórcze działanie Boga w przyrodzie. Kwestionowanie teorii ewolucji może bowiem dawać dobre samopoczucie, które wynika z przekonania, że jest się „prawdziwym” obrońcą wiary chrześcijańskiej w świecie zdominowanym przez nauki przyrodnicze. Problem jednak w tym, że w rzeczywistości taka postawa może być przejawem „powierzchowności, która poniża

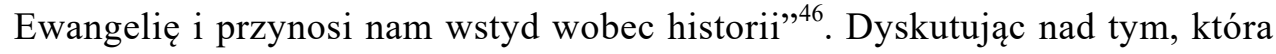
interpretacja kreacjonizmu jest bardziej adekwatna i bardziej spójna z naukowym obrazem świata, warto wystrzegać się właśnie takiego podejścia.

\section{BIBLIOGRAFIA}

Austriaco, Nicanor P. G., James Brent, Thomas Davenport, John B. Ku. Ewolucja w świetle wiary. Perspektywa tomistyczna. Tłum. Grażyna Gomola, Aleksander Gomola. Poznań: $\mathrm{W}$ drodze, 2019.

Barbour, Ian G. „Ways of Relating Science and Theology”. W: Physics, Philosophy and Theology: A Common Quest for Understanding. Red. Robert J. Russel, William Stoeger, George V. Coyne, 21-48. Vaticano: Vatican Observatory Publications, 1988.

Behe, Michael, J. Darwin's Black Box: The Biochemical Challenge for Evolution. New York: Free Press, 1996. Wyd. polskie: Czarna skrzynka Darwina - biochemiczne wyzwanie dla ewolucjonizmu. Warszawa: Megas, 2008.

Behe, Michael, J. „Irreducible Complexity: Obstacle to Darwinian Evolution”. W: Debating Design: From Darwin to DNA, red. Michael Ruse, William A. Dembski, 352-370. Cambridge: CUP, 2004.

${ }^{44}$ „Jak Heller z Pabjanem rozdawali samochody na Placu Czerwonym w Moskwie” - tak Kazimierz Jodkowski był uprzejmy zatytułować wykład (wygłoszony m.in. podczas XI Warsztatów Filozofii Przyrody w Pasierbcu 24 VI 2017 r.) poświęcony krytyce kreacjonizmu ewolucyjnego.

${ }^{45}$ MaryniarcZyK, Prawda o stworzeniu świata, 15.

${ }^{46}$ „Chrześcijanie będą niechybnie przyswajać sobie panujące poglądy na świat, a te są dziś głęboko kształtowane przez naukę. Jedynym pytaniem jest tylko, czy będzie się to dokonywało w sposób krytyczny czy też zupełnie bezrefleksyjny, z wyczuciem głębi i niuansów czy z powierzchownością, która poniża Ewangelię i przynosi nam wstyd wobec historii" - JAN PAwEL II, „Posłanie Jana Pawła II do George’a V. Coyne'a”, Zagadnienia Filozoficzne w Nauce 12 (1990), 10. 
Bronk, Andrzej. Zrozumieć świat wspótczesny. Lublin: Towarzystwo Naukowe KUL, 1998.

Bronk, Andrzej, Stanisław Majdański. „Metodologia teologii”. W: JANECZeK, WalczaK, Starościc, Metodologia nauk, t. 2, Typy nauk, 127-159.

Bronk, Andrzej, Monika Walczak. „Metoda naukowa”. W: JaneczeK, WalczaK, Starościc, Metodologia nauk, t. 1, Czym jest nauka?, 89-153.

Dembski, William A. Intelligent Design. The Bridge between Science and Theology. Downers Grove, IL: InterVarsity Press, 1999.

Dupree, A. Hunter. „Christianity and the Scientific Community in the Age of Darwin”. W: LiNDBERG, NuMBERs, God and Nature, 351-368.

Grant, Edward. „Science and Theology in the Middle Ages”. W: LindBerg, Numbers, God and Nature, 49-75.

HAJduk, Zygmunt. O akceptacji teorii empirycznej. Lublin: Wydawnictwo KUL, 1984.

Heller, Michał, Tadeusz PabJan. Stworzenie i początek wszechświata. Teologia - filozofia kosmologia. Kraków: Copernicus Center Press, 2013.

Heller, Michał, Józef Życiński. Dylematy ewolucji. Kraków: PTT, 1990.

HeLler, Michał. Czy fizyka jest nauka humanistyczną? Tarnów: Biblos, 1998.

Heller, Michał. Filozofia przypadku. Kosmiczna fuga z preludium i codą. Kraków: Copernicus Center Press 2011.

Heller, Michał. Sens życia i sens wszechświata. Studia z teologii współczesnej. Tarnów: Biblos, 2002.

JAN PAweŁ II. „Magisterium Kościoła wobec ewolucji”. L'Osservatore Romano 18, nr 1 (1997): 18-19.

Jan Pawee II. „Posłanie Jana Pawła II do George'a V. Coyne'a”. Zagadnienia Filozoficzne w Nauce 12 (1990): 2-12.

JANECZEK, Stanisław, Monika WalcZaK, Anna Starościc, red. Metodologia nauk. T. 1-2. Lublin: Wydawnictwo KUL, 2019.

KRĄPIEC, Mieczysław A. „Ewolucjonizm, ale jaki?” W: Ewolucjonizm czy kreacjonizm, red. Piotr Jaroszyński, 7-40. Lublin: Fundacja Lubelska Szkoła Filozofii Chrześcijańskiej, 2008.

JoDKowski, Kazimierz. „Kreacjoniści przed sądem. Aspekty filozoficzne «małpich procesów»”. W: Poszukiwania filozoficzne, red. Jakub Michalczenia, Jadwiga Mizińska, Katarzyna Ossowska, t. 1, Nauka, Prawda, 175-198. Olsztyn: Instytut Filozofii UWM, 2014.

LAKATOS, Imre. „Falsyfikacja a metodologia naukowych programów badawczych”. W: Imre LAKATos, Pisma z filozofii nauk empirycznych, thum. Wojciech Sady, 3-169. Warszawa: PWN, 1995.

Lemańska, Anna. „Wyjaśnianie w nauce”. W: Janeczek, Walczak, Starościc, Metodologia nauk, t. 1, Czym jest nauka?, 231-249.

Lindberg, David C., and Ronald L. Numbers, red. God and Nature: Historical Essays on the Encounter between Christianity and Science. Berkeley: University of California Press, 1986.

LindBerg, David C. „Science in the Early Church”. W: LindBerg, NumBers, God and Nature, 19-48.

Maryniarczyk, Andrzej. „Prawda o stworzeniu świata”. Nasz Dziennik, 6.12.2017.

Matzke, Nicolas. „The Evolution of Creationist Movements”. Evolution Education and Outreach 3, nr 2 (2010): 145-162.

McMuldin, Ernan. Ewolucja i stworzenie. Tłum. Jacek Rodzeń. Tarnów: Biblos, 2006.

Moore, James R. „Geologists and Interpreters of Genesis in the Nineteenth Century”. W: LiNDBERG, NumBers, God and Nature, 322-350.

Numbers, Ronald L. „The Creationists”. W: Lindberg, Numbers, God and Nature, 391-423.

PabJan, Tadeusz. Anatomia konfliktu. Między nowym ateizmem a teologia nauki. Kraków: Copernicus Center Press, 2016. 
PaBjan, Tadeusz. Świat najlepszy z możliwych? O dobroci Boga i pochodzeniu zła. Kraków: Copernicus Center Press, 2018.

Popper, Karl R. Logika odkrycia naukowego. Tłum. Urszula Niklas. Warszawa: PWN, 1977.

SŁoмKa, Marek. Działanie Boga w przyrodzie. Analiza filozoficzna. Lublin: Wydawnictwo KUL, 2018.

Teoria Inteligentnego Projektu - nowe rozumienie naukowości? Red. Kazimierz Jodkowski. Warszawa: Megas, 2007.

Tomasz, św. Suma Teologiczna. Tłum. Pius Bełch i in. London: Veritas, 1963-1986.

WĘCŁAWsKi, Tomasz. „Metodologia teologii”. Nauka 3 (2004): 101-120.

ZoN, Józef. „Nic nowego w starym sporze”. Filozoficzne Aspekty Genezy 23 (2005/2006): 25-33.

Życiński, Józef. Bóg i ewolucja. Podstawowe pytania ewolucjonizmu chrześcijańskiego. Lublin: Towarzystwo Naukowe KUL, 2002.

\section{PROJEKT CZY EWOLUCJA?}

\section{STWÓRCZE DZIAŁANIE BOGA W ŚWIECIE PRZYRODY}

\section{Streszczenie}

Artykuł poświęcono krytycznej analizie kilka wybranych argumentów pojawiających się we współczesnej dyskusji dotyczącej interpretacji stwórczego działania Boga w świecie przyrody, rozpatrywanego w kontekście teorii ewolucji. W szczególności zwrócono uwagę na zastrzeżenia wobec tej teorii wysuwane przez niektórych przedstawicieli kreacjonizmu ujętego w ramy systemu metafizyki św. Tomasza, którzy nie widzą możliwości uzgodnienia ewolucji z teologiczną prawdą o stworzeniu świata przez Boga. Rozpatrzono również argumenty leżące u podstaw teorii inteligentnego projektu, która głosi, że oparta na przypadku ewolucja nie może w sposób adekwatny wyjaśnić „nieredukowalnej złożoności” żywych organizmów, i że w związku z tym należy przyjąć, iż na przebieg procesów ewolucyjnych mają zasadniczy wpływ bezpośrednie działania Boga - Inteligentnego Projektanta.

Slowa kluczowe: kreacjonizm; ewolucja; inteligentny projekt.

\section{DESIGN OR EVOLUTION? GOD'S CREATIVE ACTION IN THE WORLD OF NATURE}

\section{S u m m a ry}

The article is devoted to the critical analysis of several arguments appearing in contemporary discussions regarding the interpretation of God's creative activity in the world of nature, considered in the context of the theory of evolution. In particular, an attention was paid to some reservations about this theory put forward by some representatives of creationism contained within the framework of St. Thomas's metaphysics, who see no way to reconcile evolution with the theological truth about God's creation of the world. The arguments underlying the theory of intelligent design were also considered. This theory claims that chance-based evolution cannot adequately explain the ,irreducible complexity” of living organisms, and that it must therefore be assumed that the course of evolutionary processes is primarily influenced by the direct actions of God — the Intelligent Designer.

Keywords: creationism; evolution; intelligent design. 